\title{
PENGARUH KARAKTERISTIK PENGELOLA KEUANGAN SEKOLAH DAN TRANSPARANSI TERHADAP EFEKTIVITAS PENGELOLAAN KEUANGAN PADA SMA DAN SMK NEGERI DI KOTA MADIUN
}

\author{
Windarti \\ Magister Akuntansi \\ Fakultas Ekonomi dan Bisnis - Universitas Sebelas Maret Surakarta
}

\begin{abstract}
ABSTRAK
Penelitian ini bertujuan untuk menganalisis pengaruh karakteristik pengelola keuangan sekolah dan transparansi terhadap efektivitas pengelolaan keuangan. Karakteristik pengelola keuangan sekolah diproksikan sebagai tingkat pendidikan, latar belakang pendidikan, usia, pengalaman, dan gender. Penelitian ini menggunakan data primer. Pengumpulan data menggunakan kuisioner yang diberikan kepada 110 pengelola keuangan SMA dan SMK Negeri di Kota Madiun. Kuisioner yang memenuhi persyaratan untuk penelitian sebanyak 72 responden. Metode analisis data menggunakan regresi ganda. Hasil penelitian membuktikan bahwa karakteristik pengelola keuangan sekolah dan transparansi secara simultan berpengaruh terhadap efektivitas pengelolaan keuangan. Tingkat pendidikan, dan pengalaman berpengaruh terhadap efektivitas pengelolaan keuangan. Latar belakang pendidikan, usia, dan gender terbukti tidak mempengaruhi efektivitas pengelolaan keuangan sekolah. Transparansi berpengaruh terhadap efektivitas pengelolaan keuangan sekolah.
\end{abstract}

Kata kunci: karakteristik, tingkat pendidikan, latar belakang pendidikan, usia, pengalaman, gender, efektivitas pengelolaan keuangan sekolah.

\section{PENDAHULUAN}

Sekolah merupakan salah satu organisasi sektor publik di bidang pendidikan yang mempunyai peran penting dalam menghasilkan generasi yang berkualitas. Kemajuan sebuah bangsa ditentukan oleh kualitas sumber daya manusia. Sumber daya manusia sangat ditentukan oleh kualitas pendidikan, karakter, dan keterampilan. Ketiga faktor tersebut dapat dibentuk melalui proses pendidikan. Tujuan pendidikan nasional adalah membentuk generasi muda yang berkepribadian, cerdas, dan mempunyai keterampilan (UU no. 20 tahun 2003). Mengingat pentingnya peran pendidikan mendorong pihak sekolah untuk terus meningkatkan kualitas atau mutu pendidikan bagi siswa (Hapenciuc, Burciu, dan Cioba 2007; Sihono dan Yusof 2012).

Peningkatan kualitas pendidikan harus didukung dengan adanya dana, sumber daya manusia, dan material (Hapenciuc et al.2007). Sumber dana sekolah berasal dari Pemerintah Pusat, Pemerintah Daerah, dan Masyarakat (Peraturan Pemerintah Nomer 48 tahun 2008). Pengelolaan dan pertanggungjawaban dana keuangan sekolah mengacu pada pengelolaan keuangan Negara. UU 17 Tahun 2003 tentang Keuangan Negara, Pasal 3 ayat (1) mengenai ketentuan pengelolaan keuangan negara menyatakan bahwa pada prinsipnya pengelolaan keuangan negara oleh pemerintah (pusat dan/daerah) harus dikelola secara tertib dan taat pada peraturan perundang-undangan, efisien, ekonomis, efektif, transparan, dan bertanggungjawab dengan memperhatikan rasa keadilan dan kepatutan. 
Keterbukaan informasi ini dapat menghasilkan perbaikan tata kelola dalam sekolah. Masyarakat dan stakeholders akan memberikan kepercayaan yang tinggi kepada pemerintah dan akan meningkatkan nilai dari sekolah. Apabila masyarakat semakin banyak mengetahui tentang organisasi/pemerintah, maka kepercayaan stakeholders akan semakin tinggi (Glasgow 2002). Permasalahan yang terjadi, penyerapan dana pendidikan khususnya di kota Madiun belum maksimal. Sekolah masih harus mengembalikan dana ke kas pemerintah daerah, padahal dana tersebut masih diperlukan. Pemerintah telah mengalokasikan dana yang cukup besar. Alokasi dana pendidikan ditentukan minimal 20\% dari APBN atau APBD. Berdasarkan data terakhir dari Dinas Pendidikan, Kebudayaan, Pemuda dan Olah Raga pada tahun 2014 dana yang harus dikembalikan sebesar 19\% dari pagu dana DIK.

Hasil penelitian tentang karakteristik seseorang menunjukkan hasil yang berbedabeda. Balta et al. (2010) menjelaskan bahwa tingkat pendidikan dan latar belakang fungsional mempengaruhi pelaporan keuangan dan proses pengambilan keputusan strategis. Seseorang dengan tingkat pendidikan yang semakin tinggi akan mempunyai pemahaman yang lebih luas daripada orang yang tingkat pendidikannya lebih rendah. Hasil penelitian ini tidak didukung oleh Wiersema dan Bantel (1992); Setyaningrum (2012); Winarna dan Murni (2006); Batubara (2008). Sutaryo (2011) juga mengungkapkan bahwa tingkat pendidikan, latar belakang pendidikan, umur, dan pengalaman kerja dapat meningkatkan kinerja pemerintah yang optimal. Yunus (2010) membuktikan bahwa karakteristik individu berpengaruh terhadap kinerja pegawai dan kepuasan konsumen.

Hasil penelitian Salsabila dan Prayudiawan (2011) tentang gender menunjukkan bahwa gender tidak berpengaruh terhadap kualitas audit. Hal ini berbeda dengan Jalbert dan Furumo (2013) yang membuktikan bahwa gender dapat mempengaruhi kinerja keuangan.Transparansi atau keterbukaan informasi merupakan hal yang penting, apalagi bagi lembaga sektor publik. Boy dan Hotniar (2009) mengungkapkan bahwa transparansi pengelolaan anggaran berpengaruh terhadap partisipasi orang tua murid. Siregar (2011) menyatakan hal yang berbeda yaitu bahwa transparansi tidak berpengaruh terhadap pengelolaan APBD. Menurut Sopanah (2003) menunjukkan bahwa interaksi antara pengetahuan anggaran dengan transparansi kebijakan publik tidak berpengaruh terhadap pengawasan APBD. Sekolah memerlukan orang-orang yang mempunyai karakteristik tertentu dengan harapan pengelolaan keuangan lebih efektif. Pengelola keuangan harus mengetahui tentang perencanaan sampai dengan pelaporan keuangan. Penempatan sumber daya manusia (SDM) harus dilaksanakan dengan tepat sesuai dengan kompetensi (Sri Mulyani 2009).

\section{KAJIAN TEORI DAN PENGEMBANGAN HIPOTESIS Teori Keagenan (Agency Theory)}

Teori Agency awalnya digunakan dalam sektor privat yang melibatkan pemilik sebagai principal yang tidak dapat mengelola sendiri perusahaannya dan menyerahkan tanggung jawab itu kepada manajer selaku agent. Teori ini menjelaskan hubungan antara pihak principal dan agent. Menurut pendapat Hill dan Jones (1992) menyatakan bahwa Teori Agency dan Stakeholder merupakan cara strategis organisasi dalam mencapai tujuannya. Sekolah sebagai lembaga pendidikan di sektor publik melibatkan beberapa stakeholder baik stakeholder internal maupun stakeholder eksternal. Kepala sekolah dan jajarannya dapat disebut agent, dan pemerintah disebut principal. Pengelola keuangan 
sekolah selaku agen mendapatkan fasilitas dan dana dari pihak principal. Pengelola bertanggung jawab atas pengelolaan dana untuk pendidikan dan pelaporan dana tersebut. Perbedaan kepentingan antara agen dan principal dapat menyebabkan terjadinya konflik.

Menurut pendapat Yusnaini (2011) mengungkapkan bahwa management control systems (MCS) diperlukan untuk mengatasi permasalahan yang terjadi karena hubungan antara agent dan principal tersebut. Hal ini penting untuk menyelaraskan antara tujuan agent dengan tujuan principal. Kontrol berkaitan dengan informasi yang disediakan untuk menilai efektivitas kebijakan, perencanaan, dan kewajiban pihak manajemen untuk melaporkan informasi kepada pihak pemilik dan pihak ekstern (Walker (1926) dalam Zeff (2008); Brief (2005). Finch dan Robertson dalam Henry, Bitter, dan Kubichan (2010) menyatakan bahwa permasalahan kerugian keuangan di sekolah dapat disebabkan karena tidak adanya kontrol yang memadai atas alokasi pengeluaran dana sekolah.

\section{Karakteristik Pengelola Keuangan}

Pengelola keuangan sekolah merupakan orang-orang yang terlibat dalam kegiatan pengelolaan keuangan yang ada di suatu sekolah. Kepala sekolah selaku manajer bertanggung jawab atas pengelolaan keuangan di sekolah. Pengelolaan keuangan di sekolah dapat dibantu oleh pihak-pihak lain seperti: bendahara, kepala tata usaha, wakil kepala sekolah, komite sekolah, dan lain-lain. Hal ini seperti yang diungkapkan oleh Herabudin (2009) dalam Kompri (2014) bahwa keterlibatan guru, petugas administrasi, bagian lainnya maupun pemerintah dapat menunjang kegiatan pengelolaan keuangan.

Latar belakang pendidikan merupakan disiplin ilmu atau bidang khusus yang diambil pada waktu menuntut ilmu ditingkat pendidikan baik SMA/SMK, Menurut pendapat Bamber et al. (2010) dalam Sutaryo (2011) menjelaskan bahwa jika seorang manajer mempunyai latar belakang pendidikan keuangan dan akuntansi, maka pemahaman mereka tentang anggaran, praktik keuangan dan akuntansi akan semakin baik. Pemahaman tentang akuntansi akan mempermudah dalam mengelola keuangan. Hal ini karena pengelolaan keuangan merupakan ilmu pengetahuan yang dipelajari apabila seseorang mempelajari tentang keuangan dan akuntansi.

Dari segi usia, manajer yang usianya lebih tua kurang mampu dalam mengintregasikan secara efektif dan mengevaluasi ide-ide baru dalam proses pengambilan keputusan. Manajer cenderung bersifat tradisional dan tertutup terhadap perkembangan baru serta memegang teguh ide-ide yang lama. Sebaliknya, manajer yang lebih muda cenderung lebih terbuka terhadap perubahan sistem yang ada dibandingkan manajer yang lebih tua. Manajer atau CFO yang lebih muda berani untuk menerapkan inovasi-inovasi yang baru dalam pengambilan keputusan.

Pengalaman merupakan suatu proses pembelajaran dan penambahan perkembangan potensi bertingkah laku baik dari pendidikan formal maupun non formal (Kovinna dan Betri 2014). Lama masa kerja seseorang dapat mencerminkan pengalamannya. Menurut Purnamasari (2005) dalam Sukriah et al. (2009) mengungkapkan bahwa kelebihan yang dimiliki oleh karyawan yang mempunyai masa kerja yang tinggi yaitu: mendeteksi kesalahan, memahami kesalahan, dan mencari penyebab terjadinya kesalahan.

Penelitian yang dilakukan oleh Collins, Colleen, dan Gordon (2004) mendapatkan hasil bahwa wanita mempunyai kemampuan untuk menyeimbangkan antara pekerjaan dan keluarga sehingga kinerja keuangan lebih baik daripada pria. Menurut Jamilah (2007) dalam Ainia (2011) gender menjadi salah satu faktor yang dapat menunjukkan perbedaan seseorang dalam melakukan pekerjaan yang kompleks. Selain itu, gender dapat memberikan pengaruh pada tingkat kepatuhan terhadap etika. Temuan riset literatur psikologis kognitif dan pemasaran juga menyebutkan bahwa wanita diduga lebih efisien dan efektif dalam memproses informasi saat adanya kompleksitas tugas dalam 
pengambilan keputusan dibandingkan dengan pria. Wanita yang mempunyai perasaan yang halus, biasanya mempunyai tingkat pertimbangan moral yang lebih tinggi dibandingkan dengan laki-laki. Hal senada diungkapkan oleh Jalbert dan Furumo (2013) bahwa manajer perempuan atau wanita mempunyai kinerja keuangan yang lebih tinggi.

\section{HIPOTESIS}

Hasil penelitian terdahulu tentang pengaruh karakteristik pengelola keuangan dan transparansi menunjukkan perbedaan. Oleh karena itu peneliti ingin menguji kembali pengaruh karakteristik pengelola keuangan di lingkungan pendidikan seperti: tingkat pendidikan, latar belakang pendidikan, usia, pengalaman, dan gender serta transparansi terhadap efektivitas pengelolaan keuangan pada SMA dan SMK Negeri di Kota Madiun. Hipotesis dalam penelitian ini dapat dirumuskan sebagai berikut:

\section{a. Tingkat Pendidikan dan Efektivitas Pengelolaan Keuangan}

Pengelola keuangan sekolah mempunyai tingkat pendidikan yang berbeda-beda mulai SMA/SMK sampai dengan S2. Tingkat pendidikan dapat menunjukkan tingkat pemahaman dan pengetahuan yang berbeda. Semakin tinggi tingkat pendidikan seseorang akan meningkatkan mutu sumber daya manusia. Orang yang mempunyai tingkat pendidikan tinggi mempunyai tingkat analisis terhadap permasalahan yang lebih tinggi daripada orang yang berpendidikan lebih rendah. Penelitian yang memberikan bukti empiris tentang pengaruh tingkat pendidikan telah dilakukan oleh Wiersema et al. (1992), Balta et al. (2010), Sutaryo (2011). Hasil penelitian menyatakan bahwa tingkat pendidikan berpengaruh terhadap kinerja keuangan dan proses pengambilan keputusan strategis. Tingkat pendidikan berpengaruh juga terhadap kualitas hasil pengawasan (Salsabila dan Prayudiawan 2011).

$\mathrm{H}_{1}$ :Tingkat pendidikan pengelola keuangan berpengaruh terhadap efektivitas pengelolaan keuangan sekolah.

\section{b. Latar Belakang Pendidikan dan Efektivitas Pengelolaan Keuangan}

Latar belakang pendidikan pengelola keuangan dapat berasal dari akuntansi, ekonomi, teknik, hukum, dan lain-lain. Mengacu pada penelitian yang dilakukan oleh Sutaryo (2011), latar belakang pendidikan dapat dibedakan menjadi dua yaitu keuangan dan akuntansi, dan non-keuangan dan akuntansi. Menurut Bamber et al. (2010) dalam Sutaryo (2011) menyatakan bahwa manajer yang mempunyai latar belakang pendidikan keuangan dan akuntansi mempunyai pemahaman yang lebih baik tentang anggaran, praktik keuangan dan akuntansi. Hal ini akan meningkatkan kinerja. Latar belakang pendidikan berpengaruh terhadap kualitas hasil pengawasan (Salsabila dan Prayudiawan 2011).

$\mathrm{H}_{2}$ : Latar belakang pendidikan pengelola keuangan berpengaruh terhadap efektivitas pengelolaan keuangan sekolah.

\section{c. Usia dan Efektivitas Pengelolaan Keuangan}

Usia pengelola keuangan sekolah dihitung sejak dilahirkan sampai sekarang. Usia dapat memberikan pengaruh terhadap kinerja dan pengambilan keputusan strategis. Bertambahnya usia seseorang akan memberikan pengaruh terhadap kemampuan kognitif dan energi atau tenaga seseorang (Pavlatos 2012). Hasil penelitian Sutaryo (2011) menyatakan bahwa semakin tinggi usia seseorang, tingkat kedewasaan dan cara berpikirnya akan semakin baik, sehingga kinerjanya juga akan meningkat. Pendapat ini diperkuat oleh Wei et al. (2005) yang menyatakan bahwa usia berpengaruh positif terhadap kinerja.

$\mathrm{H}_{3}$ :Usia pengelola keuangan berpengaruh terhadap efektivitas pengelolaan keuangan sekolah. 


\section{d. Pengalaman dan Efektivitas Pengelolaan Keuangan}

Pengalaman merupakan sumber informasi dan sumber belajar yang nyata. Pengalaman dapat membuat pola tingkah laku seseorang menjadi yang lebih tinggi dan lebih baik (Kovinna dan Betri 2014).

Menurut Purnamasari (2005) dalam Sukriah et al. (2009) mengungkapkan bahwa kelebihan yang dimiliki oleh karyawan yang mempunyai masa kerja yang tinggi yaitu: mendeteksi kesalahan, memahami kesalahan, dan mencari penyebab terjadinya kesalahan. Pengalaman dapat diukur dengan lamanya masa kerja seseorang dalam melaksanakan tugasnya. Pengalaman berpengaruh terhadap kualitas hasil pengawasan (Salsabila dan Prayudiawan 2011). Jika seseorang semakin lama melaksanakan tugas dalam pengawasan keuangan, maka akan semakin memahami tentang keuangan dan permasalahannya.

$\mathrm{H}_{4}$ : Pengalaman pengelola keuangan berpengaruh terhadap efektivitas pengelolaan keuangan sekolah.

\section{e. Gender dan Efektivitas Pengelolaan Keuangan}

Gender atau jenis kelamin seseorang dapat dibedakan menjadi dua yaitu wanita dan pria. Secara teoritis, ada pandangan yang menyatakan bahwa wanita berbeda dengan pria dalam kinerja keuangan. Wanita mempunyai kinerja keuangan yang lebih tinggi daripada pria (Jalbert dan Furumo 2013). Riset dibidang pemasaran membuktikan bahwa wanita lebih efisien dan efektif dalam memproses informasi dibandingkan dengan pria. Wanita mempunyai kemampuan untuk menyeimbangkan antara pekerjaan dan keluarga sehingga kinerja keuangan lebih baik daripada pria (Collins et al. 2004)

$\mathrm{H}_{5}$ : Gender pengelola keuangan berpengaruh terhadap efektivitas pengelolaan keuangan sekolah.

\section{f. Transparansi dan Efektivitas Pengelolaan Keuangan}

Transparansi merupakan tuntutan bagi setiap lembaga agar nilai lembaga juga meningkat. Keterbukaan informasi dan informasi yang disampaikan secara tepat waktu dan akurat merupakan perwujudan dari transparansi. Lembaga yang mempunyai tingkat transparansi yang tinggi akan membuat stakeholders memberikan kepercayaan yang tinggi pula kepada lembaga tersebut. Hasil penelitian yang dilakukan oleh Coryanata (2007) telah membuktikan bahwa transparansi kebijakan publik berpengaruh terhadap hubungan pengetahuan dewan dengan pengawasan keuangan daerah.

$\mathrm{H}_{6}$ : Transparansi berpengaruh terhadap efektivitas pengelolaan keuangan sekolah.

\section{METODE PENELITIAN}

\section{Populasi, Sampel, dan Tehnik Pengambilan Sampel}

Populasi penelitian ini adalah seluruh pengelola keuangan yang ada dalam sekolah yang terlibat langsung dalam pengelolaan keuangan sekolah. Sekolah yang digunakan meliputi: 6 (enam) Sekolah Menengah Atas (SMA) Negeri dan 5 (lima) Sekolah Menengah Kejuruan (SMK) Negeri di Kota Madiun.

Sampel pada penelitian ini adalah bagian dari populasi. Sampel penelitian ini adalah pengelola keuangan sekolah yang terdiri dari kepala sekolah, kepala tata usaha, wakil kepala sekolah, bendahara, dan komite sekolah. Penentuan sampel dengan metode purposive sampling. Jumlah sampel 110 yang diambil dari 11 sekolah. Kriteria untuk menentukan sampel adalah:

a. Kepala sekolah, wakil kepala sekolah, dan kepala tata usaha adalah yang terlibat dalam pengelolaan keuangan sekolah.

b. Guru yang diberi tugas sebagai bendahara. 
c. Pegawai atau Tata Usaha yang diberi tugas sebagai bendahara.

d. Komite sekolah yang dijadikan sampel adalah pengurus inti komite sekolah, yang meliputi ketua dan bendahara.

\section{Teknik Pengumpulan Data}

Jenis data yang digunakan dalam penelitian ini adalah data primer yaitu berupa kuisioner yang dirancang oleh peneliti. Penilaian kuisioner dengan skala likert lima poin (Sekaran 2011). Poin atau skor yang diberikan pada setiap jawaban atau respon yang diberikan responden dengan menggunakan kategori 1 sampai dengan 5 dengan interval dari kata "sangat setuju" sampai "sangat tidak setuju" Sugiyono (2008).

\section{Definisi Operasional dan Pengukuran Variabel}

Definisi variabel dan pengukurannya dapat dijelaskan sebagai berikut:

a. Variabel Bebas (Independent Variable)

Variabel independen adalah karakteristik pengelola keuangan. Karakteristik merupakan kategori atau kriteria yang dapat digunakan untuk mengetahui perbedaan individu dari aspek pengetahuan dan heuristic individu. Karakteristik pengelola keuangan dapat diukur melalui:

1) Tingkat pendidkan (Education) atau EDU $\left(\mathrm{X}_{1.1}\right)$

Pengukuran variabel tingkat pendidikan dalam penelitian ini mengacu pada penelitian yang dilakukan oleh Balta et al.(2010).Tingkat pendidikan dikelompokkan dengan skala Likert 5 yang terdiri dari: $1=\mathrm{SMA} / \mathrm{SMK} ; 2=$ $\mathrm{D} 1 / \mathrm{D} 2 / \mathrm{D} 3 ; 3=\mathrm{S} 1 ; 4=\mathrm{S} 2 ; 5=\mathrm{S} 3$.

2) Latar belakang pendidikan (Background) atau BACK (X.1.2)

Latar belakang pendidikan disiplin ilmu khusus yang dimiliki seseorang selama mengikuti pendidikan formal. Menurut Sutaryo (2011) latar belakang pendidikan responden dapat dikelompokkan menjadi dua yaitu:
$1=$
Keuangan dan Akuntansi.
$0=$
Non-keuangan dan akuntansi.

3) Usia atau AGE ( $\left.\mathrm{X}_{1.3}\right)$

Usia atau umur merupakan lama waktu hidup sejak seseorang dilahirkan sampai sekarang. Usia dihitung mulai dilahirkan sampai sekarang dengan ukuran tahun.

4) Pengalaman atau TENURE $\left(\mathrm{X}_{1.4}\right)$

Pengalaman merupakan suatu proses pembelajaran dan penambahan perkembangan potensi bertingkah laku baik dari pendidikan formal maupun non formal (Kovinna dan Betri 2014). Pengalaman diukur dengan berapa lama pengelola keuangan terlibat dalam pengelolaan keuangan baik sebagai kepala sekolah, kepala tata usaha, ketua komite, wakil kepala sekolah, maupun bendahara. Ukuran yang digunakan adalah tahun.

5) Jenis kelamin atau GENDER $\left(X_{1.5}\right)$

Gender dapat dibedakan menjadi dua yaitu laki-laki dan perempuan. Penelitian ini menggunakan kategori untuk gender yaitu:
$0=$
untuk Perempuan
$1=$
untuk Laki-laki

Variabel independen yang kedua adalah Transparansi atau TRANS $\left(\mathrm{X}_{2}\right)$. Transparansi merupakan keterbukaan dalam memberikan informasi kepada pihak- 
pihak yang memerlukan. Indikator pengukuran transparansi menurut Krina (2003) berdasarkan literatur dari berbagai sumber diantaranya adalah:

1) Penyediaan informasi yang jelas tentang prosedur-prosedur, biaya-biaya, dan tanggung jawab.

2) Kemudahan akses informasi

3) Menyusun mekanisme pengaduan jika ada pelanggaran terhadap peraturan

4) Informasi yang disediakan relevan dan tepat waktu.

Variabel transparansi diukur dengan menggunakan instrumen berupa kuisioner sebanyak 6 pernyataan dengan Skala Likert 5.

b. Variabel Terikat atau Dependent Variable (Y)

Variabel terikat dalam penelitian ini adalah Efektivitas Pengelolaan Keuangan (EFEKT). Instrumen menggunakan instrumen yang dikembangkan oleh Mardiasmo (2009) dan instrumen yang digunakan oleh Badan Akreditasi Nasional (BAN) dalam melaksanakan penilaian akreditasi terhadap sekolah (Permendikbud Nomor 59 Tahun 2012). Efektivitas pengelolaan keuangan sekolah diukur dengan menggunakan kuisioner yang mengacu pada pedoman berikut ini:

1) Pengelola keuangan sekolah sudah berhasil mencapai tujuan sekolah sesuai dengan perencanaan program.

2) Pengelola keuangan sekolah sudah melaksanakan program sekolah berkaitan dengan pengelolaan dana keuangan dengan efektif.

3) Pengelola keuangan sekolah sudah melaksanakan pengelolaan keuangan sesuai dengan peraturan yang berlaku.

4) Pengelola keuangan sekolah mengidentifikasi dan menganalisis faktorfaktor yang mendukung dan menghambat program.

5) Pengelola keuangan sekolah melaksanakan program dengan saling melengkapi sehingga program dapat dilakukan dengan biaya yang minimum.

6) Pengelola keuangan menggunakan cara dan alternatif agar program dapat dilaksanakan dengan baik.

7) Pengelola keuangan sekolah menyusun laporan sebagai bentuk pertanggung-jawaban mengenai efektivitas pengelolaan keuangan

Uji asumsi klasik perlu dilakukan supaya dapat memperoleh penelitian yang akurat. Uji asumsi klasik yang akan dilakukan meliputi: uji normalitas, uji linearitas, uji multikolinearitas, uji autokorelasi, dan uji heteroskedastisitas. Taraf signifikansi dalam penelitian ini menggunakan 0,05 (Ghozali, 2006). Teknik analisis menggunakan regresi ganda. Hasil analisis regresi berupa koefisien untuk variabel independen (Ghozali, 2006). Pengujian hipotesis dengan menggunakan program Statistical Product and Service Solutions (SPSS). Berdasarkan hipotesis penelitian yang diajukan, model penelitian yang digunakan adalah sebagai berikut:

\footnotetext{
EFEKT $=a+b_{1}$ EDUC $+b_{2}$ BACK $+b_{3}$ AGE $+b_{4}$ TENURE $+b_{5}$ GENDER $+b_{6}$ TRANSP $+\mathbf{e}$
}

Keterangan:

a $\quad=$ Konstanta

EDUC $=$ Tingkat Pendidikan

BACK $=$ Latar Belakang Pendidikan 


\begin{tabular}{ll}
\hline AGE & $=$ Usia \\
TENURE & $=$ Pengalaman \\
GENDER & $=$ Gender \\
TRANS & $=$ Transparansi \\
EFEKT & $=$ Efektivitas pengelolaan keuangan \\
$\mathrm{e}$ & $=$ error
\end{tabular}

\section{HASIL DAN PEMBAHASAN \\ Statistik Deskriptif}

Hasil pengolahan statistik deskriptif penelitian ini adalah sebagai berikut:

Tabel 1

Statistik Deskriptif

\begin{tabular}{lcccrr}
\hline \multicolumn{1}{c}{ Variabel } & N & Min & Maks & Mean & Std. Dev \\
\hline EDU & 72 & 1 & 4 & 3,03 & 0,750 \\
BACK & 72 & 1 & 5 & 2,43 & 1,537 \\
AGE & 72 & 21 & 60 & 44,94 & 6,867 \\
TENURE & 72 & 1 & 5 & 2,19 & 1,479 \\
GENDER & 72 & 0 & 1 & 0,47 & 0,503 \\
KARAKT & 72 & 29 & 69 & 53,07 & 7,446 \\
TRANS & 72 & 16 & 30 & 25,71 & 3,333 \\
EFEKT & 72 & 40 & 60 & 51,43 & 4,788 \\
\hline
\end{tabular}

Sumber: Data primer diolah, 2015

\section{Pengujian Hipotesis}

Hasil uji asumsi klasik dalam penelitian ini semunya memenuhi persyaratan Oleh karena itu, pengujian hipotesis dapat dilakukan untuk menguji ada tidaknya pengaruh variabel independen yaitu karakteristik dan transparansi terhadap variabel dependen.

a. Hasil Uji Parsial (Uji t)

Hasil Uji Parsial (Uji t) dalam penelitian ini adalah sebagai berikut:

\section{Tabel 2}

Hasil Uji Parsial (Uji t)

\begin{tabular}{lrrrrr}
\hline \multicolumn{1}{c}{ Model } & \multicolumn{1}{c}{ B } & Std. Error & \multicolumn{1}{c}{ Beta } & \multicolumn{1}{c}{ T } & \multicolumn{1}{c}{ Sig } \\
\hline EDU & 4,000 & 0,466 & 0,627 & 8,574 & 0,000 \\
BACK & 0,250 & 0,643 & 0,022 & 0,388 & 0,699 \\
AGE & 0,039 & 0,042 & 0,056 & 0,932 & 0,355 \\
TENURE & 0,395 & 0,085 & 0,311 & 4,644 & 0,000 \\
GENDER & $-1,193$ & 0,603 & $-0,125$ & $-1,979$ & 0,052 \\
TRANS & 0,234 & 0,096 & 0,163 & 2,428 & 0,018 \\
\hline
\end{tabular}

Sumber: Data primer diolah, 2015

Hipotesis pertama $\left(\mathrm{H}_{1}\right)$ dalam penelitian ini menyatakan bahwa tingkat pendidikan pengelola keuangan berpengaruh terhadap efektivitas pengelolaan keuangan sekolah. Hasil uji t menunjukkan bahwa koefisien regresi variabel tingkat pendidikan adalah 4,000 dan nilai thitung 8,574. Nilai koefisien regresi ini signifikansi pada tingkat signifikansi 0,05 diperoleh nilai $p$ value sebesar 0,000 yang berarti lebih kecil dari $\alpha=0,05$. Kesimpulan yang dapat diambil bahwa tingkat pendidikan berpengaruh positif dan signifikan terhadap efektivitas pengelolaan keuangan sekolah. 
Hipotesis kedua $\left(\mathrm{H}_{2}\right)$ dalam penelitian ini menyatakan bahwa latar belakang pendidikan pengelola keuangan berpengaruh terhadap efektivitas pengelolaan keuangan sekolah. Hasil uji t menunjukkan bahwa koefisien regresi variabel ini adalah 0,250 dan nilai thitung 0,388 . Nilai koefisien regresi ini signifikansi pada tingkat signifikansi $5 \%$ diperoleh nilai $p$ value sebesar 0,699 yang berarti lebih besar dari $\alpha=$ $5 \%$. Kesimpulan yang dapat diambil bahwa latar belakang pendidikan tidak berpengaruh terhadap efektivitas pengelolaan keuangan sekolah.

Hipotesis ketiga $\left(\mathrm{H}_{3}\right)$ dalam penelitian ini menyatakan bahwa usia pengelola keuangan berpengaruh terhadap efektivitas pengelolaan keuangan sekolah. Hasil uji t menunjukkan bahwa koefisien regresi variabel tingkat pendidikan adalah 0,039 dan nilai thitung 0,932 . Nilai koefisien regresi ini signifikansi pada tingkat signifikansi $5 \%$ diperoleh nilai $p$ value sebesar 0,355 yang berarti lebih besar dari $\alpha=5 \%$. Kesimpulan yang dapat diambil bahwa usia tidak berpengaruh terhadap efektivitas pengelolaan keuangan sekolah.

Hipotesis keempat $\left(\mathrm{H}_{4}\right)$ dalam penelitian ini menyatakan bahwa pengalaman pengelola keuangan berpengaruh terhadap efektivitas pengelolaan keuangan sekolah. Hasil uji t menunjukkan bahwa koefisien regresi variabel tingkat pendidikan adalah 0,395 dan nilai $t_{h i t u n g} 4,644$. Nilai koefisien regresi ini signifikansi pada tingkat signifikansi 5\% diperoleh nilai $p$ value sebesar 0,000 yang berarti lebih kecil dari $\alpha=$ $5 \%$. Kesimpulan yang dapat diambil bahwa pengalaman berpengaruh positif dan signifikan terhadap efektivitas pengelolaan keuangan sekolah.

Hipotesis kelima $\left(\mathrm{H}_{5}\right)$ dalam penelitian ini menyatakan bahwa gender pengelola keuangan berpengaruh terhadap efektivitas pengelolaan keuangan sekolah. Hasil uji t menunjukkan bahwa koefisien regresi variabel gender adalah -1,193 dan nilai $t_{\text {hitung }}$ 1,979 Nilai koefisien regresi ini signifikansi pada tingkat signifikansi 5\% diperoleh nilai $p$ value sebesar 0,052 yang berarti lebih besar dari $\alpha=5 \%$. Kesimpulan yang dapat diambil bahwa gender tidak berpengaruh terhadap efektivitas pengelolaan keuangan sekolah.

Hipotesis keenam $\left(\mathrm{H}_{6}\right)$ dalam penelitian ini menyatakan bahwa transparansi berpengaruh terhadap efektivitas pengelolaan keuangan sekolah. Hasil uji $t$ menunjukkan bahwa koefisien regresi variabel transparansi adalah 0,234 dan nilai $t_{\text {hitung }} 2,428$. Nilai koefisien regresi ini signifikansi pada tingkat signifikansi $5 \%$ diperoleh nilai $p$ value sebesar 0,018 yang berarti lebih kecil dari $\alpha=5 \%$. Kesimpulan yang dapat diambil bahwa transparansi berpengaruh positif dan signifikan terhadap efektivitas pengelolaan keuangan sekolah.

\section{b. Hasil Uji Koefisien Determinasi dengan Uji F}

Pengujian hipotesa dengan uji $\mathrm{F}$ atau disebut Analysis of Variance (ANOVA) dilakukan dengan melihat hasil tingkat signifikansi. Pengujian dengan tingkat signifikansi dilakukan dengan ketentuan yaitu apabila hasil signifikansi pada tabel ANOVA $<0,05$, maka $\mathrm{H}_{0}$ ditolak dan apabila ANOVA $>0,05$, maka $\mathrm{H}_{0}$ diterima. Hasil uji $\mathrm{F}$ dengan program SPSS versi 16 menunjukkan bahwa nilai $\mathrm{p}$ sebesar 0,000 dan $0,000<0,05$. Kesimpulan bahwa karakteristik dan transparansi berpengaruh terhadap efektivitas pengelolaan keuangan sekolah.

\section{c. Hasil Uji Koefisien Determinasi dengan Uji R}

Koefisien determinasi dari hasil Uji R untuk mengetahui besarnya persentase variabel dependen dapat diprediksi dengan variabel independen. 
Hasil pengujian menunjukkan bahwa nilai koefisien adjusted $R$ square adalah sebesar 0,785 atau $78,5 \%$. Kesimpulan yang dapat diambil adalah bahwa variabel efektivitas pengelolaan keuangan sekolah (Y) yang dapat dijelaskan oleh variabilit tingkat pendidikan $\left(\mathrm{X}_{1,1}\right)$, latar belakang pendidikan $\left(\mathrm{X}_{1.2}\right)$, usia $\left(\mathrm{X}_{1.3}\right)$, pengalaman $\left(\mathrm{X}_{1.4}\right)$, gender $\left(\mathrm{X}_{1.5}\right)$, dan transparansi $\left(\mathrm{X}_{2}\right)$ adalah sebesar $78,5 \%$. Efektivitas pengelolaan keuangan sebesar $21,5 \%$ dijelaskan oleh faktor-faktor lain yang belum dimasukkan dalam model penelitian ini.

\section{Uji Koefisien Regresi dengan Uji t, Uji F, dan Uji R}

Hasil pengujian hipotesis dengan Uji t, Uji F, dan Uji R sebagai berkut:

\section{Tabel 3}

Hasil Uji Hipotesis dengan Uji t, F, dan R

\begin{tabular}{lrrrr}
\hline \multicolumn{1}{c}{ Variable } & Coefficient & Std. Error & T & \multicolumn{1}{c}{ Sig. } \\
\hline C & 29.603 & 3.038 & 9.745 & 0,000 \\
EDU & 4.000 & 0,466 & 8.574 & 0,000 \\
BACK & 0,250 & 0,643 & 0,388 & 0,699 \\
AGE & 0,039 & 0,042 & 0,932 & 0,355 \\
TENURE & 0,395 & 0,085 & 4.644 & 0,000 \\
GENDER & $-1,193$ & 0,603 & $-1,979$ & 0,052 \\
TRANS & 0,234 & 0,096 & 2428 & 0,018 \\
\hline R & 0,896 & Sum of Squares & & 1307.838 \\
R-square & 0,804 & Mean Square & & 217.973 \\
Adjusted R-squared & 0,785 & F & & 44,301 \\
S. E of the Estimate & 2.218 & Sig. & & 0,000 \\
\hline
\end{tabular}

Sumber: Data primer diolah, 2015

\section{PEMBAHASAN}

Hipotesis penelitian ini adalah karakteristik pengelola keuangan sekolah (tingkat pendidikan, latar belakang pendidikan, usia, pengalaman, dan gender) dan transparansi berpengaruh terhadap efektivitas pengelolaan keuangan. Rekapitulasi hasil pengujian hipotesis secara keseluruhan dapat dilihat dalam tabel berikut ini:

Tabel 4

\section{Rekap Hasil Pengujian Hipotesis}

\begin{tabular}{clcc}
\hline Kode & \multicolumn{1}{c}{ Hipotesis } & $\alpha$ & Hasil \\
\hline $\mathrm{H}_{1}$ & $\begin{array}{l}\text { Tingkat pendidikan berpengaruh terhadap efektivitas } \\
\text { pengelolaan keuangan sekolah }\end{array}$ & 0,000 & Diterima \\
$\mathrm{H}_{2}$ & $\begin{array}{l}\text { Latar belakang pendidikan berpengaruh terhadap efektivitas } \\
\text { pengelolaan keuangan }\end{array}$ & 0,699 & Ditolak \\
$\mathrm{H}_{3} \quad \begin{array}{l}\text { Usia berpengaruh terhadap efektivitas terhadap pengelolaan } \\
\text { keuangan sekolah }\end{array}$ & 0,355 & Ditolak \\
$\mathrm{H}_{4} \quad \begin{array}{l}\text { Pengalaman berpengaruh terhadap efektivitas pengelolaan } \\
\text { keuangan sekolah }\end{array}$ & 0,000 & Diterima \\
$\mathrm{H}_{5} \quad \begin{array}{l}\text { Gender berpengaruh terhadap efektivitas pengelolaan } \\
\text { keuangan sekolah } \\
\mathrm{H}_{6}\end{array}$ & $\begin{array}{l}\text { Transparansi berpengaruh terhadap efektivitas pengelolaan } \\
\text { keuangan sekolah }\end{array}$ & 0,052 & 0,018 \\
\hline
\end{tabular}

Sumber: Data primer diolah, 2015 
Penelitian ini membuktikan bahwa tingkat pendidikan berpengaruh terhadap efektivitas pengelolaan keuangan sekolah. Semakin tinggi tingkat pendidikan maka semakin tinggi tingkat efektivitas pengelolaan keuangan sekolah. Latar belakang pendidikan tidak berpengaruh terhadap efektivitas pengelolaan keuangan sekolah. Hasil ini membuktikan bahwa pengelola keuangan yang mempunyai latar belakang pendidikan dari keuangan dan akuntansi dengan yang berasal dari non-keuangan dan akuntansi tetap dapat melaksanakan pengelolaan keuangan secara efektif. Usia tidak berpengaruh terhadap efektivitas pengelolaan keuangan sekolah. Hasil ini membuktikan bahwa semakin tinggi usia pengelola keuangan, maka tidak meningkatkan efektivitas pengelolaan keuangan sekolah.

Pengalaman berpengaruh positif dan signifikan terhadap efektivitas pengelolaan keuangan sekolah. Hasil ini membuktikan bahwa semakin lama pengalaman pengelola keuangan, maka memberikan pengaruh yang semakin baik terhadap efektivitas pengelolaan keuangan sekolah. Bahkan apabila pengelola keuangan bukan berasal dari disiplin ilmu keuangan dan akuntansi, tetap dapat menjalankan pengelolaan keuangan sekolah dengan efektif apabila sudah mempunyai pengalaman dalam mengelola keuangan sekolah. Hal ini disebabkan karena pengelola keuangan telah mengetahui tentang permasalahan tentang pengelolaan keuangan mulai dari perencanaan sampai dengan pelaporan keuangan.

Gender tidak berpengaruh terhadap efektivitas pengelolaan keuangan sekolah. Hasil ini membuktikan baik pengelola keuangan berjenis kelamin laki-laki maupun perempuan, tidak memberikan pengaruh pada efektivitas pengelolaan keuangan sekolah. Pengelola keuangan wanita tidak memberikan pengaruh yang lebih baik terhadap efektivitas pengelolaan keuangan daripada pengelola keuangan pria. Efektivitas pengelolaan keuangan tidak tergantung pada gender pengelola keuangan sekolah. Transparansi berpengaruh terhadap efektivitas pengelolaan keuangan sekolah. Hal ini membuktikan bahwa tuntutan adanya transparansi atau keterbukaan informasi kepada publik akan meningkatkan efektivitas pengelolaan keuangan sekolah.

\section{KESIMPULAN DAN SARAN}

Hasil penelitian berdasarkan pembahasan membuktikan bahwa karakteristik pengelola keuangan sekolah dan transparansi secara simultan berpengaruh terhadap efektivitas pengelolaan keuangan. Tingkat pendidikan, pengalaman pengelola keuangan sekolah dan transparansi berpengaruh terhadap efektivitas pengelolaan keuangan. Latar belakang pendidikan, usia, dan gender terbukti tidak mempengaruhi efektivitas pengelolaan keuangan sekolah. Transparansi berpengaruh terhadap efektivitas pengelolaan keuangan sekolah.

Saran yang dapat diberikan kepada peneliti berikutnya berdasarkan hasil penelitian yang telah dilakukan adalah sebagai berikut:

a. Bagi peneliti berikutnya dapat menambah objek dan sampel penelitian, tidak hanya untuk SMA dan SMK Negeri saja tetapi meliputi semua tingkatan sekolah mulai dari SD sampai dengan SMA/SMK/MA. Hasil yang dicapai diharapkan dapat digeneralisasi.

b. Variabel penelitian ditambah dengan variabel lain seperti Internal Control, Standar Pengendalian Intern Pemerintah, Tekanan Organisasi atau yang lain. Transparansi dapat dijadikan sebagai variabel moderating. 
c. Variabel dependen ditambah dengan variabel lain seperti Efisiensi Pengelolaan Keuangan.

\section{DAFTAR PUSTAKA}

Adewale, Aregbeshola R. dan Munano M. Esther. 2012. The Relationship Between Stakeholders' Involvement In Strategic Planning and Organisation's Performance A Study Of The University Of Venda. International Business \& Economics Research Journal. Volume 11, Number 11: 1175-1190.

Alip, Moch. dan Sunarto. 2008. Peran Komite Sekolah dalam Penyelenggaraan SMK di DIY. Jurnal Penelitian dan Evaluasi Pendidikan, Nomor 1, Tahun XI: 145-161

Balta, Maria Elisaver. Adrian Woods. Keith Dickson. 2010. The Influence Of Boards Of Directors' Characteristics On Strategic Decision- Making: Evidence From Greek Companies. The Journal of Applied Business Research. 26, 3: pg. 57.

Barrett, Pat. 1997. Public sector reform: Bringing it together. Vol. 67. Australia Business And Economics--Accounting. Journal of Economics.

Bastian, Indra. 2007. Akuntansi Pendidikan. Erlangga Jakarta.

Batubara, R. Iskandar. 2008. Analisis Pengaruh Latar Belakang Pendidikan, Kecakapan Profesional, Pendidikan Berkelanjutan, dan Independensi Pemeriksa Terhadap Kualitas Hasil Pemeriksaan. Studi Empiris Pada Bawasko Medan. Tesis S2 USU.

Boy, Denny. Hotniar, S. 2009. Analisis Pengaruh Akuntabilitas Dan Transparansi Pengelolaan Anggaran Pendapatan Dan Belanja Sekolah (APBS) Terhadap Partisipasi Orang Tua Murid. Jurnal Ekonomi Bisnis. No. 12 Vol. 14: 79-87.

Brief, Policy. 2005. Public Sector modernization: The way forward. Report of Organization of Economic Co-operation and Development. (OECD).

Collins-Dodd, Colleen. Gordon, Irene M. Smart, Carolyne. 2004. Further Evidence on the Role of Gender in Financial Performance. Journal of Small Business Management. Vol. 42, No. 4: 395-417.

Coryanata, Isma. 2007. Akuntabilitas, Partisipasi Masyarakat, dan Transparansi Kebijakan Publik Sebagai Pemoderating Hubungan Pengetahuan Dewan tentang Anggaran dan Pengawasan Keuangan Daerah (APBD). Jurnal Simposium Nasional Akuntansi X.

Dawkins, Cedric E. 2014. The Principle of Good Faith: Toward Substantive Stakeholder Engagement. Business Ethics Journal. 121: 283-295

Direktorat Jenderal Pendidikan Dasar, Kemendiknas dan Direktorat Jenderal Pendidikan Islam, Kemenag RI. 2011. Peningkatan Manajemen Melalui Penguatan Tata Kelola dan Akuntabilitas di Sekolah/Madrasah. Materi Pelatihan Sekolah/Madrasah.

Edelenbos, J. and Klijn, E-H. 2006. Managing Stakeholder Involvement in Decision Making: A Comparative Analysis of Six Interactive Processes in the Netherlands. Journal of Public Administration Research and Theory. 16(3): 417-446.

EUNEC. 2011. Participation and Stakeholder Involvement in Education Policy Making. Report of the conference of the European Network of Education.

Glasgow, Bo.2002. Corporate governance: A time for change--public and private sector measures move forward. New York, Reed Business Information UK: 24-26

Ghozali, Imam. 2006. Aplikasi Analisis Multivariate dengan Program SPSS. Semarang: UNDIP

Hapenciuc, C. V. , A. Burciu, dan G. Cioban. 2007. Implementation Of The System Of The Management of Education Quality, Basic Requirement For E.U. Integration. SSRN Journal: $1-9$ 
Henry, Laurie J. Michael E. Bitter. Terry Kubichan. 2010. TheViolet Bay School District Deficit of 2005: Evaluating Internal Control and Identifying Risks. Issues In ccounting Education. American Accounting Association Vol. 25, No. 1:119-153.

Hill, Charles W. L. Jones, Thomas M. 1992. Stakeholder - Agency Theory. Journal of Management Studies. 29: 131-154.

Jalbert, Terrance. Mercedes Jalbert. Kimberly Furumo. 2013. The Relationship Between CEO Gender, Financial Performance, and Financial Management. Journal of Business \& Economics Research. Volume 11, Number 1: 25-34.

Kaihatu, T. S.. 2006. Good Corporate Governance dan Penerapannya di Indonesia. Jurnal Manajemen dan Kewirausahaan. Vol. 8, No. 1: 1 - 9

Kamus Besar Bahasa Indonesia. 1984.

King Report. 2002. Executive Summary King Report on Corporate Governance. Institute of Directors in Southern Africa, Parktown

Kovinna, Fransiska dan Betri. 2014. Pengaruh independensi, pengalaman kerja, kompetensi, dan etika auditor terhadap kualitas audit. Jurnal Akuntansi STIE MDP: $1-14$.

Krina, Loina Lalolo P. 2003. Indikator \& Alat Ukur Prinsip Akuntabilitas, Transparansi \& Partisipasi, Sekretariat Good Public Governance Badan Perencanaan Pembangunan Nasional, Jakarta

Krismiaji. Y. Anni, Ariyani. 2011. Akuntansi Manajemen. Yogyakarta: YKPN.

Kompri. 2014. Manajemen Sekolah. Teori dan Praktek. Bandung: Alfabeta.

Mardiasmo. 2006. Pewujudan Transparansi dan Akuntabilitas Publik melalui Akuntansi Sektor Publik: Suatu Sarana Good Governance. Jurnal Akuntansi Pemerintah. Vol. 2, No. 1: 16-37.

Mardiasmo. 2009. Akuntansi Sektor Publik. Yogyakarta: Andi.

OECD, 2002. Principle of Good Corporate Government. OECD, Paris.

Pavlatos, Odysseas. The impact of CFOs' characteristics and information technology on cost management systems. Journal of Applied Accounting Research. Vol. 13 No. 3: 242-254.

Rahmawati. 2012. Teori Akuntansi Keuangan. Yogyakarta: Graha Ilmu.

Republik Indonesia. Undang-Undang Nomor 17 Tahun 2003 Tentang Keuangan Negara. Undang-Undang Nomor $20 \quad$ Tahun $2003 \quad$ Tentang Sistem Pendidikan Nasional.

Peraturan Pemerintah Nomor 48 tahun 2008 tentang Pendanaan pendidikan.

Peraturan Menteri Pendidikan dan Kebudayaan Nomor 59 Tahun 2012 tentang Badan Akreditasi Nasional.

Salsabila, Ainia., dan H. Prayudiawan. 2011. Pengaruh Akuntabilitas, Pengetahuan Audit Dan Gender Terhadap Kualitas Hasil Kerja Auditor Internal (Studi Empiris Pada Inspektorat Wilayah Provinsi DKI Jakarta). Jurnal Telaah \& Riset Akuntansi. Vol. 4. No. 1: $155-175$.

Sekaran, Uma. 2007. Research Methods For Business. Jakarta: Salemba Empat

Setyaningrum, Dyah. 2012. Analisis Faktor-Faktor yang Mempengaruhi Kualitas Audit BPK-RI. Jurnal Simposium Nasional Akuntansi XV.

Siregar, Liper. 2011. Pengaruh Akuntabilitas Publik, Transparansi Publik dan Pengawasan terhadap Pengelolaan APBD dengan Standar Akuntansi Pemerintahan Sebagai Variabel Moderator pada Pemerintah Kota Pematangsiantar. Jurnal Sultanist. Edisi I: 21-27. 
Sopanah. Mardiasmo. 2003. Pengaruh Partisipasi Masyarakat dan Transparansi Kebijakan Publik Terhadap Hubungan Antara Pengetahuan Dewan Tentang Anggaran Dengan Pengawasan Keuangan Daerah. Jurnal Simposium Nasional Akuntansi VI.

Sukriah, Ika. Akram. Biana. 2009. Pengaruh Pengalaman Kerja, Independensi, Obyektifitas, Integritas dan Kompetensi Terhadap Kualitas Hasil Pemeriksaan. Jurnal Simposium Nasional Akuntansi XII.

Sutaryo. Jaka, Winarna. 2013. Karakteristik DPRD dan Kinerja Penyelenggaraan Pemerintah Daerah: Dukungan Empiris dari Perspektif Teori Keagenan Jurnal Simposium Nasional Akuntansi XVI.

Sutedjo. 2009. Persepsi Stakeholders Terhadap Transparansi Dan Akuntabilitas Pengelolaan Keuangan Sekolah (Studi Kasus Di Sekolah Menengah Pertama Standar Nasional Kabupaten Kendal). Tesis S2 UNDIP.

Sugiyono. 2008. Statistika untuk Penelitian. Alfabeta Bandung.

Sutaryo. 2011. Karakteristik Eksekutif dan Kinerja Keuangan Pemerintah Daerah (Sebuah Telaah Teoritis dan Empiris). Jurnal Maksi. Vol VII: 1-7.

Sihono, Teguh. Rohaila, Yusof. 2012. Implementation of School Based Management in Creating Effective Schools. International Journal of Independent Research and Studies - IJIRS. Vol. 1, No.4: 142-152.

Thomas, Howard. Lynne, Thomas. 2011. Perspectives on leadership in business schools. Journal of Management Development. Vol. 30 No. 5: 526-540.

Wei, Li-Qun. Chung-Ming, Lau. Michael, N. Young. Zhihui, Wang. 2005. The Impact of Top Management Team Demography on Firm Performance in China. Asian Business \& Management Journal. Vol. 4: 227-250.

Wiersema, Margarethe F. Karen A., Bantel. 1992. Top Management Team Demography and Corporate Strategic Change. Academy of Management Journal. Vol. 35. No. 1: 91-121

Winarna, Jaka. Sri, Murni. 2006. Pengaruh Personal Backgroun, Political Background, dan Pengetahuan Dewan Tentang Anggaran Terhadap Peran DPRD dalam Pengawasan Keuangan Daerah. Simposium Nasional Indonesia X.

Yunus, H. Eddy. Pengaruh Kepemimpinan, Karakteristik Individu, dan Budaya Organisasi terhadap Kinerja Pegawai Dinas Pendidikan dan Pariwisata dan Kepuasan Konsumen Industri Pariwisata di Jawa Timur. Jurnal Aplikasi Manajemen. Vol. 8, No. 4: 961-970.

Yusnaini. 2011. Agency Theory dan Managements Control Systems dalam Konteks Budaya Asia. Jurnal Ekonomi dan Informasi Akuntansi (Jenius). Vol. 1 No. 1:37-45

Zeff, Stephen A. 2008. The Contribution of the Harvard Business School to Management control 1908-1980. Journal Of Management Accounting Research Volume Twenty, Special Issue pp. 175-208. 